\title{
Influence of Nitrogen Content on the Corrosion Behavior of Powder Metallurgy Nickel-Free Austenitic Stainless Steel
}

\author{
Weili Yu, ${ }^{1}$ Changhai Du, ${ }^{1}$ Hongren Shen, ${ }^{1}$ Hao He, ${ }^{2}$ Yong Yu, ${ }^{3}$ Yimin Li, ${ }^{1}$ \\ and Fenghua Luo $\mathbb{D}^{1}$ \\ ${ }^{1}$ State Key Laboratory of Powder Metallurgy, Central South University, Changsha 410083, China \\ ${ }^{2}$ Research Centre for Materials Science and Engineering, Guangxi University of Science and Technology, Liuzhou 545006, China \\ ${ }^{3}$ Hunan Injection High Technology Co. Ltd., Changsha 410083, China
}

Correspondence should be addressed to Fenghua Luo; fenghualuo@csu.edu.cn

Received 5 August 2021; Accepted 5 October 2021; Published 14 October 2021

Academic Editor: Antonio Riveiro

Copyright (c) 2021 Weili Yu et al. This is an open access article distributed under the Creative Commons Attribution License, which permits unrestricted use, distribution, and reproduction in any medium, provided the original work is properly cited.

Herein, powder metallurgy gas-solid nitriding was used to prepare a high-nitrogen Ni-free austenitic stainless steel with more than $1.0 \mathrm{wt} . \%$ N. Study of the microstructures and corrosion resistances of the as-prepared samples revealed that the corrosion weight loss, size, number of corrosion pits, and corrosion depth decreased as the $\mathrm{N}$ content increased from 1.19 to 1.37 wt.\%. The selfcorrosion current densities of the alloys were determined from their potentiodynamic polarization curves. The changes in the capacitive arc radius as demonstrated by the Nyquist curves were consistent with the conclusions of the immersion corrosion analysis; that is, a high $\mathrm{N}$ content leads to a high corrosion resistance.

\section{Introduction}

Owing to its excellent comprehensive performance, high-N Nifree austenitic stainless steel (HNNS) has a wide range of applications, such as medicine, shipbuilding, petroleum, nuclear power, and automobile industries [1]. Compared with Cr$\mathrm{Ni}$ austenitic stainless steel, HNNS contains high $\mathrm{Mn}$ and $\mathrm{N}$ contents and an extremely low Ni content [2]. SS304 does not contain Mo and is prone to pitting corrosion in an environment with Cl. Meanwhile, SS316 contains Mo, which increases the compactness and adhesion strength of the passivation film, thereby effectively improving the corrosion resistance against $\mathrm{Cl}$ ions. However, the content of $\mathrm{Ni}$, which is more expensive than Mn and N, in SS304 (8-10.5\%) is lower than that in SS316 (10-14\%). Thus, the cost of HNNS is lower than that of Nicontaining stainless steel. Furthermore, with $\mathrm{N}$ as the austenite phase-forming element of stainless steel, its addition can improve the mechanical properties and corrosion resistance of stainless steel. $\mathrm{N}$ can also stabilize the austenite phase and significantly improve the mechanical properties and corrosion resistance of stainless steel $[3,4]$. HNNS avoids potential problems related to Ni allergy [5-7].
The main methods of preparing HNNS are high-pressure $\mathrm{N}_{2}$ gas smelting [8-10] and atmospheric pressure smelting $[2,11]$. However, both these methods have their disadvantages. For instance, high-pressure gas atomization in the highpressure smelting method uses high-pressure $\mathrm{N}_{2}$ as the atomizing gas to atomize the melt into powder [9]. Rapid solidification can ensure that $\mathrm{N}_{2}$ in the molten metal will not precipitate during the quenching process. In addition, this considerably increases the $\mathrm{N}$ content in the steel powder and can prepare high-N steel (>1.0 wt.\%) [9]; however, this also poses issues, such as high-pressure $\mathrm{N}_{2}$ safety hazards [9], high cost [12], use of complex equipment [13], and difficult operation [14]. Meanwhile, in the atmospheric smelting method, solid powder nitriding can be used to complete the nitriding of the solid powder at low pressures and temperatures [11]. The solubility of $\mathrm{N}$ in the austenite phase with a high $\mathrm{Cr}$ content is significantly higher than that in the liquid phase; therefore, solid powder nitriding can avoid defects, such as uneven $\mathrm{N}$ content and pore formation in the general casting and production of high- $\mathrm{N}$ steel. In addition, the atmospheric pressure smelting method has the advantages of low cost [8] and low risk [15]. 
However, only medium-to-low-N smelted stainless steel with a low $\mathrm{N}$ content can be achieved by this method [16].

The $\mathrm{N}$ content in stainless steel has solid-solution strengthening effects, which can accelerate the repassivation of the metal surface and effectively inhibit local corrosion in an environment containing $\mathrm{Cl}^{-}$, such as seawater [17-20]. Ahila et al. [17] showed that a considerable number of $\mathrm{N}$ atoms aggregates at the boundary between the metal and passivation film. $\mathrm{N}_{2}$ can effectively induce the reformation of the passivation film, thereby inhibiting the occurrence of pitting corrosion. The pitting resistance of HNNS can be measured by the pitting resistance equivalent numbers (PRENs, PREN = wt.\% [Cr] + 3.3 wt.\% [Mo] +30 wt.\% [N]) [18]. When the material has a high proportion of $N$, its PREN is higher, and its pitting resistance is stronger. Simultaneously, the addition of $\mathrm{N}$ hinders the nucleation and growth of Cr-rich carbides, thereby preventing the reduction of $\mathrm{Cr}$ content in the grain boundaries and improving the resistance of stainless steel to intergranular corrosion $[21,22]$. $\mathrm{N}$ can enhance the anticorrosion effects of $\mathrm{Cr}$ and Mo to form a layer on the steel surface that is more resistant to local corrosion, inhibit the excessive passivation of the steel surface, and slow down the dissolution of $\mathrm{Cr}, \mathrm{Mo}$, and other elements of austenitic stainless steel [23].

Several studies have reported $[24,25]$ the influence of $\mathrm{N}$ content on the corrosion resistance of stainless steel. Austenitic stainless steels with $\mathrm{N}$ contents of 0.14 and 0.19 wt.\% were prepared using a high $\mathrm{N}_{2}$ gas pressure melting method, and they exhibited corrosion rates of $1.86 \times 10^{-5}$ and $1.57 \times 10^{-5} \mathrm{~g} \mathrm{~mm}^{-2} \mathrm{~h}^{-1}$, respectively, in a $6 \% \mathrm{FeCl}_{3}$ solution $\left(25 \pm 1^{\circ} \mathrm{C}, 144 \mathrm{~h}\right)$. This indicates that a low corrosion rate, which corresponds to a high $\mathrm{N}$ content, leads to a high corrosion resistance [24]. Exfoliation corrosion experiments were conducted in a previous study using the sulfuric acid-flow Fe method [25]. Austenitic stainless steels with $\mathrm{N}$ contents of 0.59 and 0.31 wt. $\%$ were immersed in a $6.8 \mathrm{~mol} \mathrm{~L}^{-1} \mathrm{H}_{2} \mathrm{SO}_{4}+$ $0.1 \mathrm{~mol} \mathrm{~L}^{-1} \mathrm{Fe}_{2}\left(\mathrm{SO}_{4}\right)$ solution $\left(25^{\circ} \mathrm{C}, 24 \mathrm{~h}\right)$. After immersion, several corrosion grooves appeared along the grain boundary on the surface of austenitic stainless steel with $0.31 \mathrm{wt} . \% \mathrm{~N}$. The grooves stretched deeply into the matrix, which resulted in the grains peeling off the matrix body significantly. Under the same conditions, only a few particles peeled off the surface of austenitic stainless steel with 0.59 wt. $\% \mathrm{~N}$. Hence, $\mathrm{N}$ improved the exfoliation corrosion resistance of stainless steel.

Ni plating on the surface of stainless steel can improve its surface conditions and resist the entry of $\mathrm{Cl}^{-}$, thereby improving its corrosion resistance, expanding its scope of application, and prolonging its service life. However, compared with the conventional stainless steel $\mathrm{Ni}$ coating, there are several limitations to the application of Ni plating to HNNS for improving the corrosion resistance. The matrix surface of HNNS is prone to defects, such as inclusions and dislocations. These defects alter the uniformity, increase the fragility of the passivation film, and increase the inflow of the $\mathrm{Cl}^{-}$ions through the defects, thereby damaging the passivation film.

Few studies have evaluated the effects of $\mathrm{N}$ contents higher than 1.0 wt.\% on the corrosion resistance of Ni-free austenitic stainless steels. In this study, gas-solid nitriding and powder metallurgy were used to prepare HNNS with higher density and $\mathrm{N}$ content (>1.0 wt.\%) than those of $\mathrm{N}$ austenitic stainless steel obtained by high $\mathrm{N}_{2}$ gas pressure melting. The effects of the difference in $\mathrm{N}$ contents on the microstructure and corrosion resistance of HNNS were examined. The corrosion mechanism was analyzed based on uniform and pitting corrosion.

\section{Materials and Methods}

In this study, $0 \mathrm{Cr} 17 \mathrm{Mn} 11 \mathrm{Mo} 3 \mathrm{~N}$ grade stainless steel powder provided by Hunan Hengji Powder Technology Co., Ltd. was used. Its chemical composition is shown in Table 1, and the powder morphology is shown in Figure 1.

The stainless steel powder was mixed with a binder (paraffin wax) and cold mold pressing was performed at $400 \mathrm{MPa}$. The sample size was $11 \mathrm{~mm} \times 8 \mathrm{~mm} \times 2.8 \mathrm{~mm}$. Nitriding and sintering were performed in a low-pressure sintering furnace (SJL-200L, Shanghai Jujing Precision Instrument Manufacturing Co., Ltd.). The temperature was increased to $600^{\circ} \mathrm{C}$ with an initial vacuum pressure of less than $0.1 \mathrm{~Pa}$. Thereafter, the temperature was maintained at $600^{\circ} \mathrm{C}$ for $1 \mathrm{~h}$. Under a constant temperature, the $\mathrm{N}_{2}$ gas pressure was increased to $20 \mathrm{kPa}$. Subsequently, the temperature was increased to $1280^{\circ} \mathrm{C}$ at a rate of $3^{\circ} \mathrm{C} \cdot \mathrm{min}^{-1}$, and the $\mathrm{N}_{2}$ gas pressure was simultaneously increased to $80 \mathrm{kPa}$. The temperature and $\mathrm{N}_{2}$ gas pressure were then maintained for $2 \mathrm{~h}$ during the completion of the nitriding treatment. After the nitriding treatment, the furnace was cooled to $1100^{\circ} \mathrm{C}$. Vacuum denitrification was then performed at $1100^{\circ} \mathrm{C}$, and the temperature was sustained for different lengths of time to provide steels with different $\mathrm{N}$ contents. The vacuum denitrification treatment times were 1,2 , and $3 \mathrm{~h}$ under a vacuum pressure of less than $0.1 \mathrm{~Pa}$. The three sintered steels were then cooled to below $100^{\circ} \mathrm{C}$ inside the furnace.

The three sintered steels underwent solid-solution treatment in a quartz tube furnace (SG-GS1700, Shanghai Shinbae Industrial Co., Ltd.) at $1200^{\circ} \mathrm{C}$ for $2 \mathrm{~h}$ under an $\mathrm{Ar}$ gas atmosphere. Following the completion of the temperature holding time, the quartz tube was clamped, broken immediately, and quenched in water. A wire-cut electric discharge machine (TZT27-DK7725, POSITTEC) was used to cut along the longitudinal section of the sintered steel to obtain a sample with a width of $1 \mathrm{~mm}$. All parts of the sintered steels were powdered after cleaning the surface oxide layer. The $\mathrm{N}$ contents of the sintered steels were determined from the aforementioned powders using an $\mathrm{O}_{2}, \mathrm{~N}_{2}$, and $\mathrm{H}_{2}$ analyzer (TCH-600, LECO). The $\mathrm{N}$ contents of the steels subjected to denitrification treatment for 1,2 , and $3 \mathrm{~h}$ were measured to be $1.19,1.28$, and 1.37 wt.\%, respectively.

X-ray diffraction (XRD; D8 Advance, Bruker) was used to determine the phase composition of the sintered alloy denitrified at $1100^{\circ} \mathrm{C}$ for $2 \mathrm{~h}$ and those of the three solidsolution alloys with different $\mathrm{N}$ contents. The sample used for the test was a block with dimensions of $11 \mathrm{~mm} \times 2.8 \mathrm{~mm}$ $\times 2 \mathrm{~mm}$. The following parameters were used for the analysis: step length $=0.02^{\circ}$, dwell time $=6 \mathrm{~s}$, and scanning angle $=30-85^{\circ}$. The sample position and measured area were moved immediately below the light barrier. 
TABLE 1: Elemental composition of the raw stainless steel powder (wt.\%).

\begin{tabular}{lcccccc}
\hline $\mathrm{C}(\%)$ & $\mathrm{N}(\%)$ & $\mathrm{Cr}(\%)$ & $\mathrm{Mn}(\%)$ & Mo (\%) & Si (\%) & $\mathrm{Fe}(\%)$ \\
\hline 0.02 & 0.26 & 17.10 & 10.20 & 3.50 & 0.64 & Bal. \\
\hline
\end{tabular}

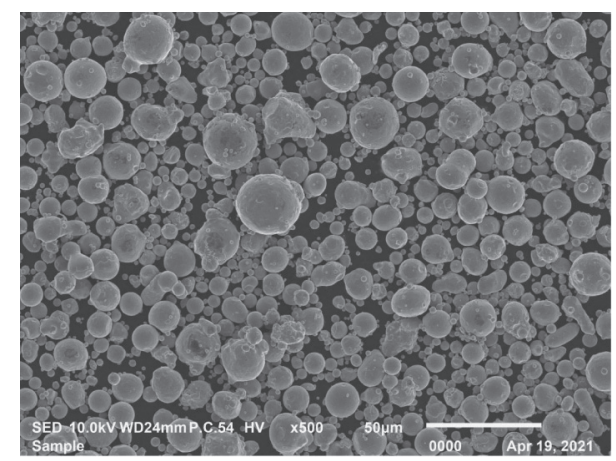

Figure 1: Micromorphology of raw steel powder.

The material test sample was cut using wire-cut electrical discharge machining. The sample was then polished with sandpaper (320\#, 600\#, 800\#, 1000\#, 1200\#, and 2000\#) and was subjected to metallographic polishing (2.5, 1.5, and $0.5 \mu \mathrm{m}$ ) until a mirror-like and scratch-free surface was achieved. An aqueous solution of $\mathrm{FeCl}_{2}$ and $\mathrm{HCl}$ acid was used as the etching agent (concentration ratio: $5 \mathrm{~g}$ $\mathrm{FeCl}_{3}+50 \mathrm{~mL} \mathrm{HCl}+100 \mathrm{~mL} \mathrm{H}_{2} \mathrm{O}$ ). Depending on the state of the sample, the corrosion time was varied from 5 to $60 \mathrm{~s}$. An optical microscope (DM2700 M, Leica) was used to observe and analyze the corroded samples.

A uniform corrosion experiment was conducted in accordance with the GB/T 17897-2016 standard using $100 \mathrm{~g}$ analytical pure iron trichloride $\left(\mathrm{FeCl}_{3} \cdot 6 \mathrm{H}_{2} \mathrm{O}\right)$, which meets the requirements of $\mathrm{HG} / \mathrm{T} 3474 . \mathrm{FeCl}_{3} \cdot 6 \mathrm{H}_{2} \mathrm{O}$ was dissolved in $900 \mathrm{~mL}$ distilled water and a $6 \% \mathrm{FeCl}_{3}$ soaking solution was prepared. The sample was polished step-by-step with 320\#-2000\# sandpaper. Before soaking, the sample was ultrasonically cleaned with distilled water, acetone, and anhydrous alcohol and dried. The $6 \% \mathrm{FeCl}_{3}$ solution was used for soaking. The ratio of the sample surface area to volume of the soaking solution was $1 \mathrm{~cm}^{2}: 20 \mathrm{~mL}$, the soaking temperature was $55 \pm 1^{\circ} \mathrm{C}$, and the soaking time was $72 \mathrm{~h}$. Following the immersion, a solution of $50 \mathrm{~mL} \mathrm{HNO}_{3}+$ $100 \mathrm{~mL} \mathrm{HF}+350 \mathrm{~mL} \mathrm{H}_{2} \mathrm{O}$ was used at $25^{\circ} \mathrm{C}$ to heat the sample for $10 \mathrm{~min}$ to remove the corrosion products deposited on its surface. Then, ultrasonic cleaning was continued with absolute ethanol for $10 \mathrm{~min}$. The sample was subsequently dried at $60^{\circ} \mathrm{C}$ for $8 \mathrm{~h}$. The mass of the sample before and after immersion was weighed using an analytical balance (AE124, Sunny Hengping) with a precision reading of $0.1 \mathrm{mg}$. The corrosion rate of the sample was calculated according to the following equation:

$$
\text { corrosion rate }=\frac{w_{\text {front }}-w_{\text {rear }}}{S \cdot t}
$$

where $W_{\text {front }}$ is the mass of the sample before soaking $(\mathrm{g})$, $W_{\text {rear }}$ is the mass of the sample after soaking $(\mathrm{g}), S$ is the surface area of the sample before soaking $\left(\mathrm{mm}^{2}\right)$, and $t$ is the soaking time $(h)$.

For the electrochemical experiment, CHI750 electrochemical workstation was used (Shanghai Chenhua Instrument Co., Ltd.). The electrochemical test sample (working electrode) was sealed with epoxy resin to achieve an exposed area of $0.25 \mathrm{~cm}^{2}$. Before the test, the sample was polished and washed with deionized water. The electrochemical test was carried out using a three-electrode system with a Pt electrode as the auxiliary electrode and a saturated calomel electrode (SCE) as the reference electrode. The potentials used in this study were relative to the reference electrode. After soaking the working electrode for $3 \mathrm{~min}$, an electrochemical impedance spectroscopy (EIS) test was performed. The electrochemical test solution was a 3.5 mass $\% \mathrm{NaCl}$ solution saturated at room temperature. The scanning rate of the polarization curve was $0.002 \mathrm{mV} \mathrm{s}^{-1}$, and the corrosion potential and corrosion current density of the sample were estimated using the Tafel extrapolation method. The EIS measurement frequency range was $10^{5}-10^{-2} \mathrm{~Hz}$. The equivalent circuit in ZSimpWin software was selected to fit the impedance data to obtain the relevant charge transfer resistance and other parameters.

The corrosion morphology of the sample surface was observed and analyzed using scanning electron microscopy (FEG 250, Quanta). After immersion and corrosion, the sample was ground according to the metallographic sample preparation method, and the corrosion depth of the sample was directly analyzed using an optical microscope.

\section{Results}

Figure 2 shows the metallographic structure and XRD pattern of the sintered alloy denitrified at $1100^{\circ} \mathrm{C}$ for $2 \mathrm{~h}$. Figure 2(a) shows that the sintered alloy was divided into three layers from the surface toward the center. The inner layer had single equiaxed grains; the middle layer had the structure of a grain boundary network or granular precipitated phases; and the outermost layer had several lamellar structures similar to pearlite colonies (ferrite/cementite lamellar) $[26,27] . \mathrm{Cr}_{2} \mathrm{~N}$ and $\mathrm{CrN}$ peaks were observed in the XRD pattern shown in Figure 2(b), suggesting that the precipitates in Figure 2(a) were $\mathrm{Cr}_{2} \mathrm{~N}$ and $\mathrm{CrN}[28,29] . \mathrm{Cr}_{2} \mathrm{~N}$ commonly forms in stainless steel with high $\mathrm{N}$ content through discontinuous solubilization [30]. Therefore, during the nitriding and sintering processes, the surface layer of the sintered alloy had a relatively high $\mathrm{N}$ content. First, $\mathrm{Cr}_{2} \mathrm{~N}$ and $\mathrm{CrN}$ discontinuously precipitated along the grain boundaries, grew into grains, and precipitated in a cellular shape, which was then arranged in a parallel lamellar shape that covered the entire grain. The $\mathrm{N}$ content of the intermediate layer was reduced, and $\mathrm{Cr}_{2} \mathrm{~N}$ and $\mathrm{CrN}$ were discontinuously precipitated in the form of short rods at the grain boundaries. There is insufficient $\mathrm{N}$ content in the sintered body because of $\mathrm{Cr}_{2} \mathrm{~N}$ precipitation. The nitriding and sintering processes employed in this study resulted in a structure with inhomogeneous $\mathrm{N}$ distribution. Hence, solution treatment was required to impart homogeneity to the alloy microstructure. 


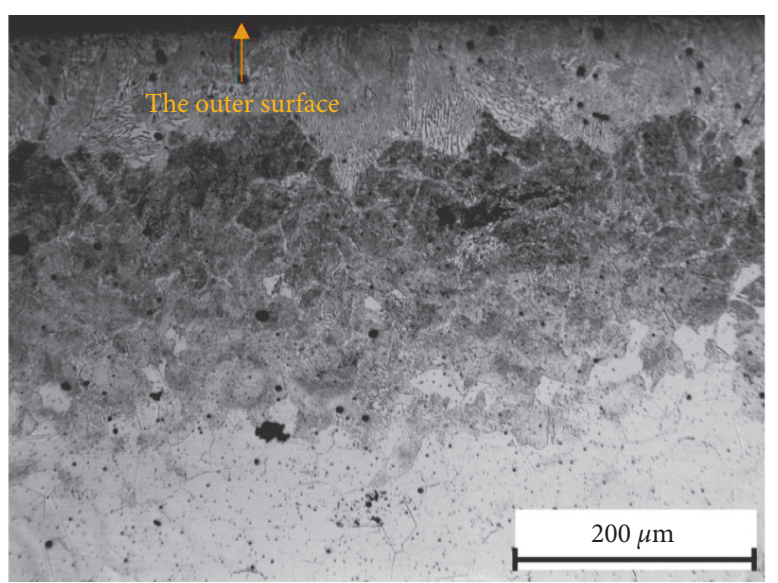

(a)

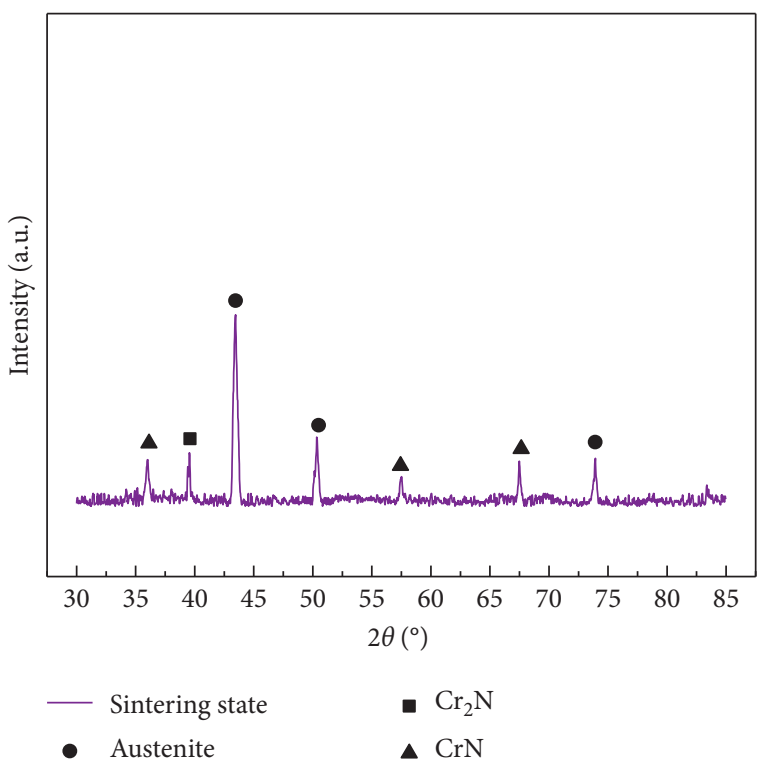

(b)

FIGURE 2: (a) Metallographic structure of the sintered alloy and (b) its XRD pattern.

Figure 3 shows the metallographic structure and XRD pattern of the alloy after the solution treatment at $1200^{\circ} \mathrm{C}$. The $\mathrm{N}$ content of the three alloys shown in Figure 3 was determined to be $1.19,1.28$, and $1.37 \mathrm{wt} . \%$. After the solution treatment, the samples with different $\mathrm{N}$ contents were identified to be austenite with relatively straight grain boundaries. There were no differences observed in their grain sizes or nitride precipitation on their grain boundaries; however, a small number of twins and pores were found. The sample with $1.19 \mathrm{wt} . \% \mathrm{~N}$ had the smallest number of pores (25) and smallest pores among the three samples (Figure 3(a)). The pore sizes of the sample with $1.28 \mathrm{wt. \%} \mathrm{N}$ (Figure 3(b)) were similar to those of the sample with 1.19 wt.\% N; however, there are more pores (36) for the former. The sample with $1.37 \mathrm{wt} . \% \mathrm{~N}$ (Figure 3(c)) exhibited larger pores and a higher number of pores (49) than those of the other two samples. These pores were mainly distributed at the intersections of the grain boundaries. Hence, these results show that an increase in the $\mathrm{N}$ content tended to increase the number of pores. A matrix with more pores, which are mostly open holes, results in poor corrosion resistance of the matrix [31]. Figure 3(d) shows the XRD pattern of the solid-solution alloy. When the $\mathrm{N}$ content was high, the matrix was in the austenite phase. Owing to the high $\mathrm{N}$ content of the matrix, a small amount of $\mathrm{Cr}_{2} \mathrm{~N}$ existed.

Samples with different $\mathrm{N}$ contents were immersed in a $55^{\circ} \mathrm{C} 6 \% \mathrm{FeCl}_{3}$ solution for $72 \mathrm{~h}$, and the weight loss of the samples before and after immersion was determined. The corrosion rate change rule is shown in Table 2. After the solution treatment at $1200^{\circ} \mathrm{C}$, the corrosion rate of the matrix decreased with an increase in the $\mathrm{N}$ content.

Figure 4 shows the surface morphologies of the solutiontreated alloys after their immersion in a $6 \% \mathrm{FeCl}_{3}$ solution at $55^{\circ} \mathrm{C}$ for $72 \mathrm{~h}$. Under the same corrosive environment, pitting corrosion occurred on the surfaces of all three HNNS samples. Because of the high immersion temperature, the corrosion pits on the substrate surface were small and spherical with a shape similar to that of the fish scales. The fish-scale pits formed on the surface of the HNNS sample with 1.19 wt.\% N (Figure 4(a)) were larger and deeper than those formed on the surfaces of the other two HNNS samples. When the $\mathrm{N}$ content was increased from 1.19 to $1.28 \mathrm{wt} . \%$ (Figure 4(b)), the size and depth of the pits on the corroded surface decreased. When the $\mathrm{N}$ content was further increased to $1.37 \mathrm{wt}$ \% (Figure 4(c)), the corrosion surface became smooth and the size and depth of the pits on the corroded surface decreased. The size and depth of the corrosion pits of a substrate can characterize its corrosion resistance. At the same solid-solution temperature, an increase in the $\mathrm{N}$ content of the substrate decreased the diameter of the pits formed on the surface of HNNS after corrosion; thus, the corrosion surface no longer showed fishscale pits. In other words, the resistance of the matrix improved with an increase in the $\mathrm{N}$ content.

Figure 5 shows the corrosion depth of the solutiontreated alloy immersed in $6 \% \mathrm{FeCl}_{3}$ solution at $55^{\circ} \mathrm{C}$ for $72 \mathrm{~h}$. The solution-treated alloys with the $\mathrm{N}$ contents of $1.19,1.28$, and 1.37 wt.\% showed immersion corrosion depths of $178.29,145.39$, and $118.01 \mu \mathrm{m}$, respectively. As the $\mathrm{N}$ content increased, the corrosion depth decreased and the corrosion resistance of HNNS improved, which is consistent with the immersion weight loss results summarized in Table 2.

Figure 6 shows the potentiodynamic polarization curve of $\mathrm{HNNS}$ in $3.5 \% \mathrm{NaCl}$ solution. The corresponding electrochemical parameters are listed in Table 3. Figure 6 shows the presence of a passivation zone in the polarization curve, with its range varying with the $\mathrm{N}$ content. As the $\mathrm{N}$ content increased from 1.19 to $1.37 \mathrm{wt} . \%$, the passivation zone of HNNS widened, the polarization curve gradually moved 


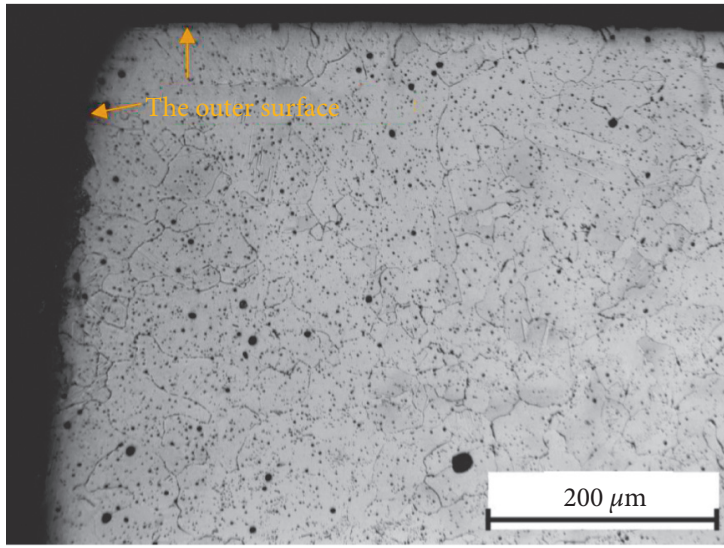

(a)

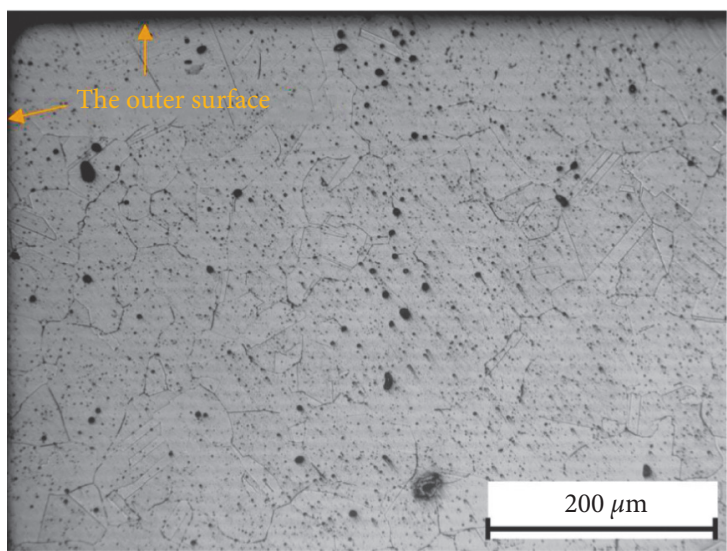

(c)

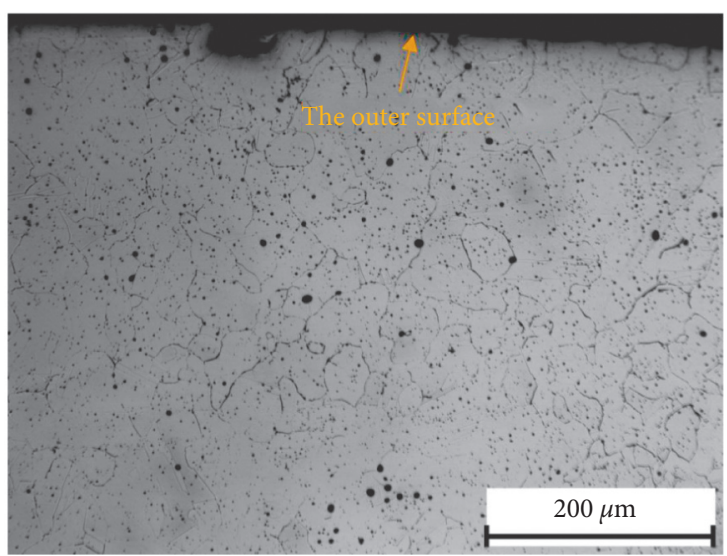

(b)

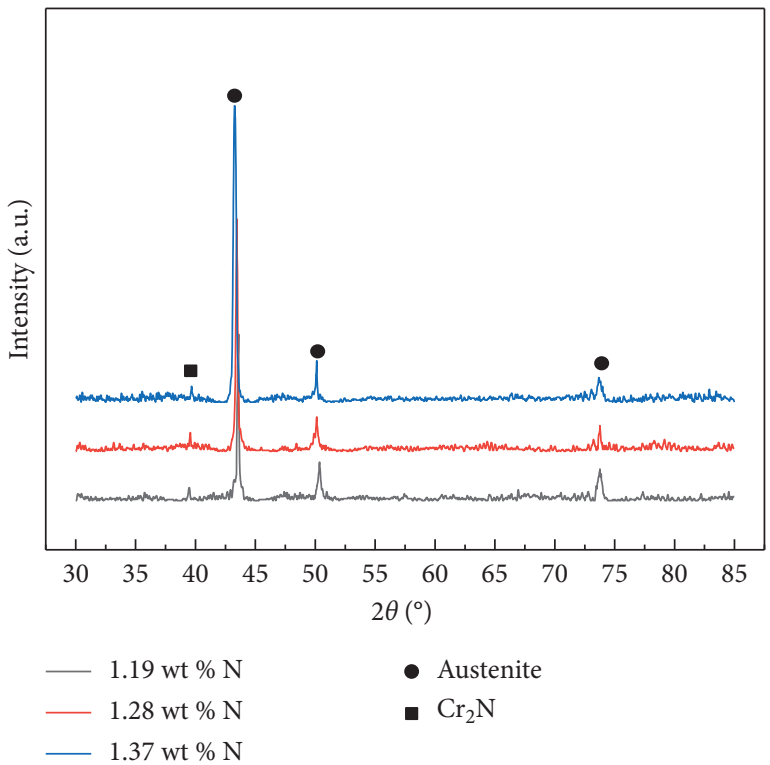

(d)

Figure 3: Metallographic structures of the solid-solution alloys with (a) 1.19 wt.\% (N), (b) 1.28 wt.\% (N), (c) 1.37 wt.\% (N), and (d) their XRD patterns.

TABle 2: Corrosion rates of the HNNS samples with different $\mathrm{N}$ contents.

\begin{tabular}{|c|c|}
\hline Temperature $\left({ }^{\circ} \mathrm{C}\right)-\mathrm{N}$ content (wt.\%) & Corrosion rate $\left(\mathrm{g} \cdot \mathrm{mm}^{-2} \cdot \mathrm{h}^{-1}\right)$ \\
\hline $1200-1.19$ & $1.74 \times 10^{-5}$ \\
\hline $1200-1.28$ & $1.43 \times 10^{-5}$ \\
\hline $1200-1.37$ & $1.11 \times 10^{-5}$ \\
\hline
\end{tabular}

upward, and the corrosion potential increased. As shown in Table 3, as the $\mathrm{N}$ content increased from 1.19 to $1.37 \mathrm{wt} . \%$, the corrosion current density of HNNS in $3.5 \% \mathrm{NaCl}$ solution decreased from $5.96 \times 10^{-7}$ to $3.14 \times 10^{-7} \mathrm{~A} \mathrm{~cm}^{-2}$, and the corrosion potential increased from -0.469 to $-0.377 \mathrm{~V}$. Thus, with increasing $\mathrm{N}$ content, the corrosion current density of HNNS decreased and the corrosion potential increased.

The corrosion potential $\left(E_{\text {corr }}\right)$ of a material can be used to characterize its corrosion resistance ability, where large $E_{\text {corr }}$ values correspond to strong corrosion resistance. The corrosion current density $\left(I_{\text {corr }}\right)$ reflects the corrosion rate, where low $I_{\text {corr }}$ values correspond to slow corrosion rates, which indicate strong corrosion resistance [32]. Wu et al. [33] studied the potentiodynamic polarization curves of $\mathrm{N}$-containing stainless steel with different $\mathrm{N}$ contents (0.66-0.82 wt.\%) in $3.5 \% \mathrm{NaCl}$ solution, in which the highest corrosion potential was obtained from the sample with 0.82 wt. $\% \mathrm{~N}$. Thus, the higher the $\mathrm{N}$ content of HNNS, the stronger is its corrosion resistance. The changing law is consistent with the findings of this study. 


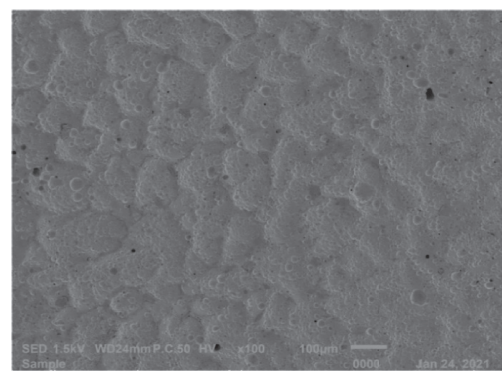

(a)

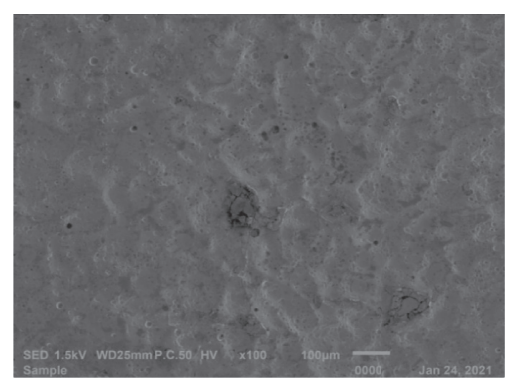

(b)

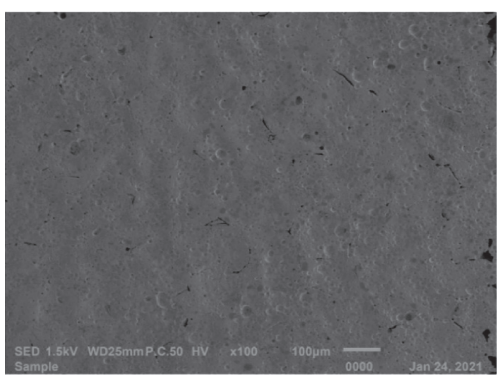

(c)

FIGURE 4: Corrosion surface morphology of the HNNS samples after their immersion in a $6 \% \mathrm{FeCl}_{3}$ solution at $55^{\circ} \mathrm{C}$ for 72 (h): (a) 1.19 wt. $\%$ $(\mathrm{N}),(\mathrm{b}) 1.28$ wt.\% $(\mathrm{N})$, and (c) 1.37 wt.\% N.

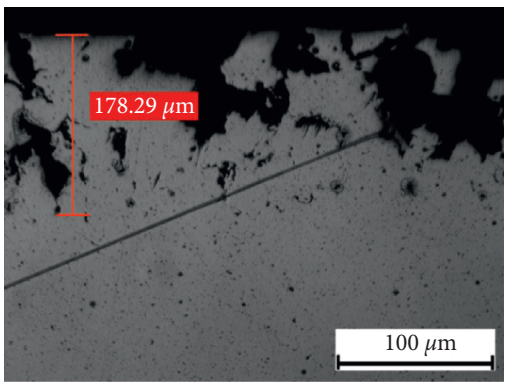

(a)

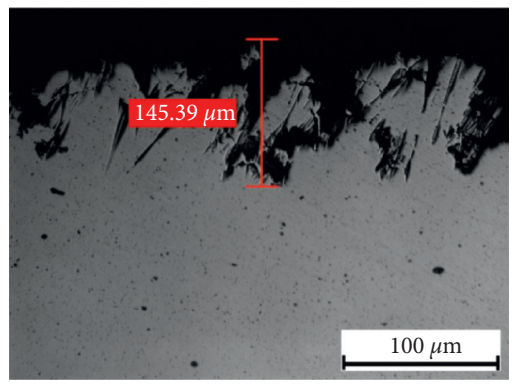

(b)

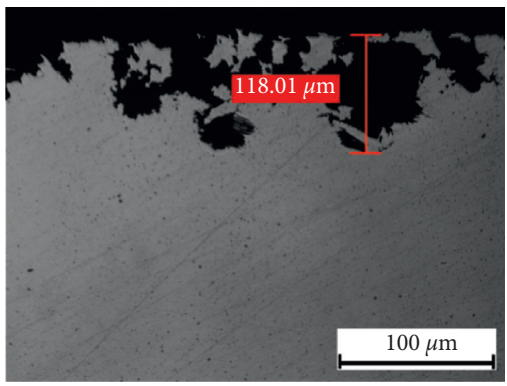

(c)

FiguRE 5: Corrosion depth of the HNNS samples after their immersion in a $6 \% \mathrm{FeCl}_{3}$ solution for 72 (h): (a) 1.19 wt. \% (N), (b) 1.28 wt. $\%$ (N), and (c) 1.37 wt.\% N.

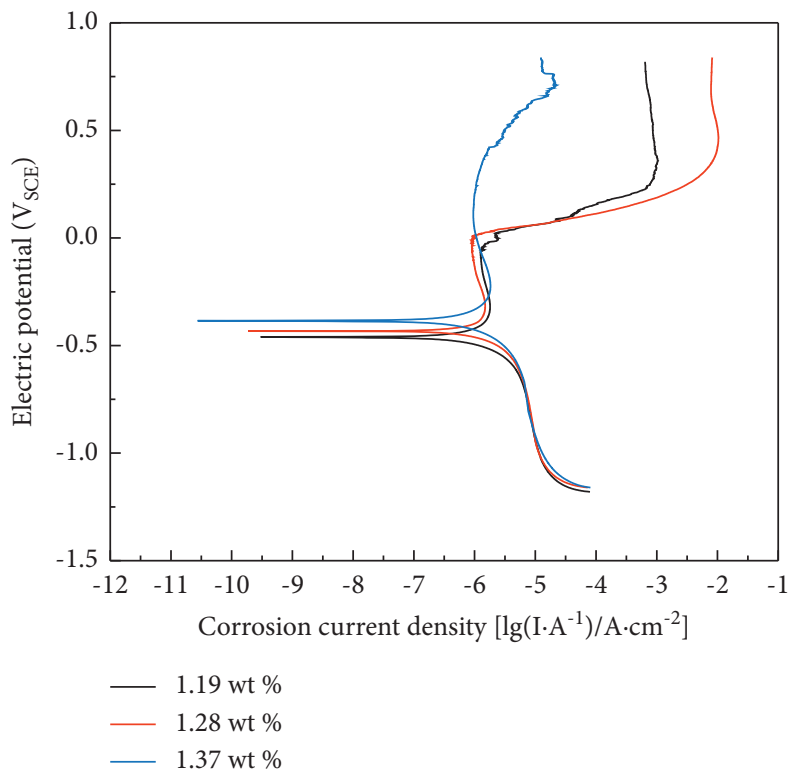

FIGURE 6: Polarization curves of HNNS with different N contents.

Figure 7 shows the Nyquist curves of the HNNS samples in a $3.5 \% \mathrm{NaCl}$ solution. In the Nyquist diagram, the capacitive arc radius can be used to characterize the corrosion resistance of the material. A large capacitive arc radius leads to a stable passivation film formed on the surface of a sample, which endows the alloying element with a high dissolution and strong corrosion resistance [34]. EIS measurements carried out under the passivation potential revealed that HNNS with 1.37 wt.\% N showed the largest capacitive arc radius, whereas HNNS with 1.19 wt.\% $\mathrm{N}$ showed the smallest capacitive arc radius, among all the samples examined in this study. The corrosion resistance of the samples with different 
TABLE 3: Electrochemical parameters of the HNNS samples with different $\mathrm{N}$ contents.

\begin{tabular}{lcc}
\hline Temperature $\left({ }^{\circ} \mathrm{C}\right)-\mathrm{N}$ content $(\mathrm{wt} . \%)$ & $\mathrm{E}_{\mathrm{corr}}(\mathrm{V})$ & $\mathrm{I}_{\mathrm{corr}}\left(\mathrm{A} \cdot \mathrm{cm}^{-2}\right)$ \\
\hline $1200-1.19$ & -0.469 & $5.96 \times 10^{-7}$ \\
$1200-1.28$ & -0.425 & $4.83 \times 10^{-7}$ \\
$1200-1.37$ & -0.377 & $3.14 \times 10^{-7}$ \\
\hline
\end{tabular}

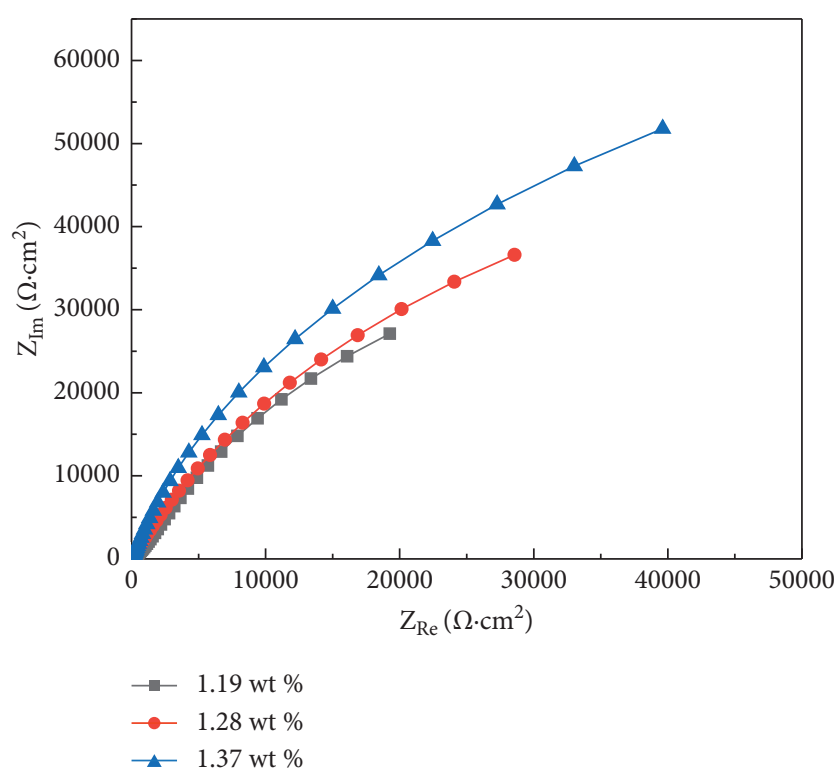

Figure 7: Nyquist diagram of the HNNS samples with different $\mathrm{N}$ contents in a $3.5 \% \mathrm{NaCl}$ solution.

$\mathrm{N}$ contents was ordered as follows: 1.37 wt. $\%>1.28$ wt. $\%>$ 1.19 wt. $\%$. These changes are consistent with the findings of the potentiodynamic polarization curve.

The Nyquist plots of the samples were numerically fitted using the equivalent circuit shown in Figure 8 , where $R_{\text {sol }}$ represents the resistance of the electrolyte, $R_{1}$ represents the resistance of the pores in the film, $R_{\mathrm{ct}}$ represents the resistance of the passivation film, $Q$ represents the pseudocapacitance of the film, and $C$ is the double electric layer capacitance [35]. Table 4 lists the main electrochemical parameters obtained after fitting the EIS equivalent circuit. At the same solid-solution temperature, as the $\mathrm{N}$ content of HNNS increased from 1.19 to 1.37 wt.\%, its $R_{\mathrm{ct}}$ increased from $1.51 \times 10^{5}$ to $2.91 \times 10^{5} \Omega \mathrm{cm}^{2}$ (Table 4).

The structure of the sintered HNNS was not uniform, and nitride precipitates were present on its surface. The $\mathrm{N}$ content of HNNS was found to influence its reaction with $\mathrm{Cr}$, in which a high $\mathrm{N}$ content accelerated the reaction. First, the discontinuous precipitations at the grain boundary appeared as round dots or short rods that precipitated to form crystal cells and finally arranged into parallel layers to form a lamellar shape. Following the solution treatment at $1200^{\circ} \mathrm{C}$, the matrix entered the homogeneous austenite phase. After immersion in $6 \% \mathrm{FeCl}_{3}$ solution at $55^{\circ} \mathrm{C}$ for $72 \mathrm{~h}$, the alloys with different $\mathrm{N}$ contents experienced mass loss and corrosion pits appeared on their surfaces. As the $\mathrm{N}$ content increased, the size and number of the corrosion pits on the surface of the substrate decreased, and the corrosion depth decreased. The potentiodynamic polarization curves and EIS results demonstrated that alloys with high $\mathrm{N}$ content exhibited high corrosion potentials, low current densities, and large capacitive reactance arc radii. Accordingly, HNNS with 1.37 wt.\% $\mathrm{N}$ exhibited the highest corrosion resistance among all three HNNS samples investigated in this study.

\section{Discussion}

Increasing the $\mathrm{N}$ content is a highly effective approach for improving the corrosion resistance of austenitic stainless steel [36, 37]. Figure 9 shows the corrosion diagram of HNNS. In the initial stage of corrosion, $\mathrm{Fe}$ in the matrix easily oxidizes because of $\mathrm{H}^{+}$produced by hydrolysis in the solution, generating soluble $\mathrm{Fe}^{2+}$ ions. $\mathrm{Fe}^{2+}$ further hydrolyzes to form $\mathrm{Fe}(\mathrm{OH})_{2}$, which easily reacts with $[\mathrm{O}]$ in the passivation film to form a metal hydroxide, $\mathrm{FeOOH}$ (equations (2)-(4)).

These equations show that a large amount of $\mathrm{H}^{+}$may exist on the surface of the sample, particularly inside the corrosion pits, which aggravates the corrosion. When a large amount of $[\mathrm{N}]$ is dissolved in the matrix, $[\mathrm{N}]$ reacts with water to generate $\mathrm{OH}^{-}$(equation (5)), which can neutralize the $\mathrm{H}^{+}$generated in reaction (4) and inhibit the acidification of the solution in the corrosion hole:

$$
\begin{gathered}
\mathrm{Fe}+2 \mathrm{H}^{+}=\mathrm{Fe}^{2+}+\mathrm{H}_{2} \\
\mathrm{Fe}^{2+}+2 \mathrm{H}_{2} \mathrm{O}=\mathrm{Fe}(\mathrm{OH})_{2}+2 \mathrm{H}^{+} .
\end{gathered}
$$




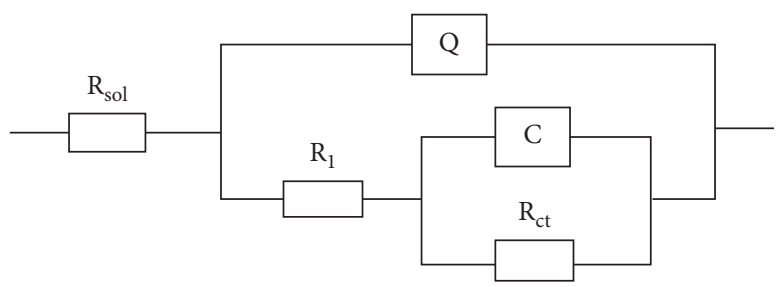

FIgURE 8: Fitted equivalent circuit.

TABLE 4: EIS equivalent circuit fitting parameters.

\begin{tabular}{lcccccc}
\hline Temperature $\left({ }^{\circ} \mathrm{C}\right)-\mathrm{N}$ content $(\mathrm{wt} . \%)$ & $R_{\text {sol }}\left(\Omega \cdot \mathrm{cm}^{2}\right)$ & $R_{c t}\left(\Omega \cdot \mathrm{cm}^{2}\right)$ & $R_{1}\left(\Omega \cdot \mathrm{cm}^{2}\right)$ & $\mathrm{n}$ & $C\left(\mathrm{~F} \cdot \mathrm{cm}^{-2}\right)$ & $Q\left(\Omega{ }^{-1} \cdot \mathrm{s}^{\mathrm{n}} \cdot \mathrm{cm}^{-2}\right)$ \\
\hline $1200-1.19$ & 5.61 & $1.51 \times 10^{5}$ & 4.78 & 0.85 & $5.11 \times 10^{-6}$ & $1.28 \times 10^{-4}$ \\
$1200-1.28$ & 4.83 & $2.38 \times 10^{5}$ & 4.27 & 0.77 & $8.34 \times 10^{-6}$ & $1.12 \times 10^{-4}$ \\
$1200-1.37$ & 4.66 & $2.91 \times 10^{5}$ & 6.66 & 0.79 & $7.29 \times 10^{-6}$ & $1.04 \times 10^{-4}$ \\
\hline
\end{tabular}

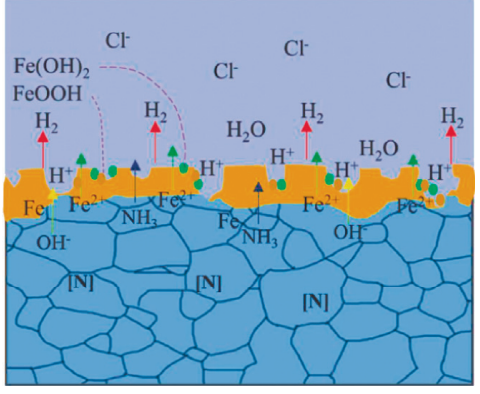

(a)

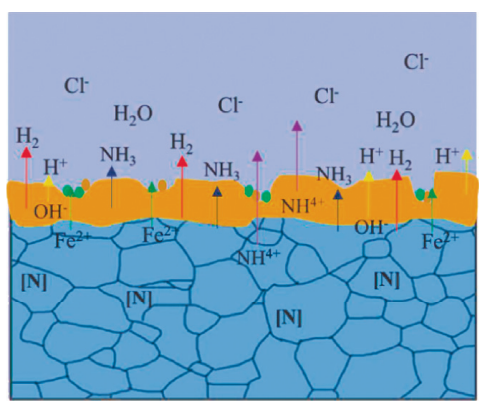

(b)

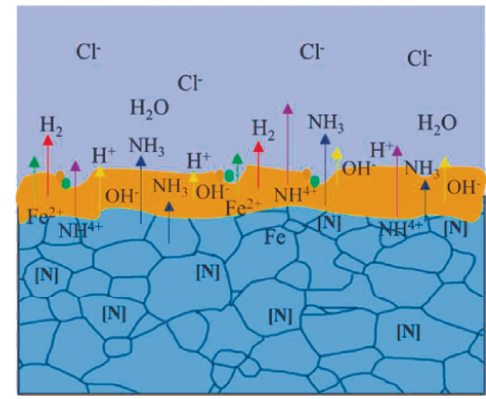

(c)

Figure 9: Schematic for the corrosion of the HNNS samples with (a) 1.19 wt.\% (N), (b) 1.28 wt.\% (N), and (c) 1.37 wt.\% N.

$$
\begin{aligned}
\mathrm{Fe}(\mathrm{OH})_{2} & =\mathrm{FeOOH}+\mathrm{H}^{+}+\mathrm{e}^{-} \\
{[\mathrm{N}]+3 \mathrm{H}_{2} \mathrm{O}+3 \mathrm{e}^{-} } & =\mathrm{NH}_{3}+3 \mathrm{OH}^{-}
\end{aligned}
$$

When the content of $[\mathrm{N}]$ in the matrix increases, as shown in Figure 9(b), more [N] is consumed in reaction (4), which consequently produces more $\mathrm{OH}^{-}$, reduces the $\mathrm{H}^{+}$ concentration in the corrosion hole, and inhibits the continued corrosion of the matrix. This also prevents the increased size and depth of the corrosion pits. Cr23Ni4Mo2N is an austenitic stainless steel with $1.0 \mathrm{wt} \% \mathrm{~N}$. When its [N] content is dissolved, $[\mathrm{N}]$ in $\mathrm{NH}^{4+}$ is stabilized [20]. When the $[\mathrm{N}]$ content in the matrix further increases, $[\mathrm{N}]$ can directly produce $\mathrm{NH}^{4+}$ by reacting with $\mathrm{H}^{+}$hydrolyzed in the solution, as shown in reaction (6). Accordingly, at high $\mathrm{N}$ contents, the solid-solution $[\mathrm{N}]$ reacts with $\mathrm{H}^{+}$before it reacts with other elements, such as Fe (Figure 9(c)). The reaction prevents the dissolution of the metal matrix and corrosion pits on the surface of the matrix, reduces the number of overall corrosion pits of the sample, and enhances the corrosion resistance of the sample:

$$
[\mathrm{N}]\left[+4 \mathrm{H}^{+}+3 \mathrm{e}^{-}=\mathrm{NH}^{4+} .\right.
$$

The above analysis is based on the acid consumption theory [16]. Increasing $\mathrm{N}$ content can also be attributed to the surface enrichment [38, 39] and synergy [40, 41] theories. Considering the surface enrichment theory, a small amount of $\mathrm{Cr}_{2} \mathrm{~N}$ is present in the sample after solid solution due to the high $\mathrm{N}$ content of the matrix. During the passivation process, $\mathrm{Cr}_{2} \mathrm{~N}$ is enriched on the surface of the passivation film, and its $\mathrm{N}$ element reacts with water to generate $\mathrm{NH}_{3}$ and $\mathrm{NH}^{4+}$ along with a small amount of $\mathrm{NO}_{3}{ }^{-}$. As shown in reaction (7), the generated $\mathrm{NO}_{3}{ }^{-}$can inhibit the surface of the etch pits through repassivation, which can stabilize the passivation film and prevent pit growth $[32,33]$ :

$$
[\mathrm{N}]+3 \mathrm{H}_{2} \mathrm{O}=\mathrm{NO}_{3^{-}}+6 \mathrm{H}^{+}+5 \mathrm{e}^{-} .
$$

When the $\mathrm{N}$ content of the substrate increases, the $\mathrm{Cr}_{2} \mathrm{~N}$ content of the sample increases. The amount of $\mathrm{NO}_{3}{ }^{-}$ generated by the reaction also increases, which improves the ability of the sample to stabilize its passivation film and enhances its resistance to metal dissolution after its passivation film is destroyed. This results in an enhancement of the corrosion resistance of the sample.

According to the synergy theory [40,41], the pitting equivalent equation (8) shows that an increase of $1 \mathrm{wt} . \%$ in the $\mathrm{N}$ content of stainless steel is equivalent to an increase of 30 wt.\% in its $\mathrm{Cr}$ content [18]. Thus, the high $\mathrm{N}$ content of a sample results in a strong pitting resistance: 


$$
\mathrm{PREN}=\mathrm{wt} \%[\mathrm{Cr}]+3.3 \mathrm{wt} . \%[\mathrm{Mo}]+30 \mathrm{wt} . \%[\mathrm{~N}] .
$$

The highest $\mathrm{N}$ content of the HNNS samples prepared in this study was $1.37 \mathrm{wt} . \%$. The effect of a further increase in the $\mathrm{N}$ content in improving the corrosion resistance of HNNS remains uncertain. In future, HNNS with higher $\mathrm{N}$ contents than the current samples will be prepared, and the relationship between its solid-solution $\mathrm{N}$ content and corrosion resistance will be investigated.

Compared with traditional austenitic stainless steel, high-N steel prepared by the powder metallurgy gas-solid nitriding method has a higher matrix $\mathrm{N}$ content. In SUS 304 stainless steel matrix, the $\mathrm{Ni}$ content is $8-11 \mathrm{wt} . \%$ without Mo. Meanwhile, the Ni content in SUS 316 stainless steel matrix is 10-14 wt.\% with an Mo content of 2-3 wt.\%. The high-N steel matrix in this study contains 3.5 wt.\% Mo. Compared with SUS304, high-N steel is more resistant to $\mathrm{Cl}^{-}$corrosion. An et al. [42] studied the pitting corrosion resistance of Cr23Mo1N HNNS and $316 \mathrm{~L}$ stainless steel in $\mathrm{Cl}^{-}$-containing solutions. After immersion in the corrosive solution $\left(6 \% \mathrm{FeCl}_{3}, T=35^{\circ} \mathrm{C}\right.$, $t=7 \mathrm{~d}$ ), the corrosion rates of HNNS and $316 \mathrm{~L}$ stainless steel were calculated to be $5.37 \times 10^{-3}$ and $9.07 \mathrm{~g} \mathrm{~m}^{-2} \mathrm{~h}^{-1}$, respectively. This indicates the strong corrosion resistance of HNNS, that is, its pitting corrosion resistance is better than that of SUS 304 and 316 stainless steel. Therefore, a high $\mathrm{N}$ content in the matrix results in strong corrosion resistance.

\section{Conclusions}

(1) The powder metallurgy gas-solid nitriding method was used to prepare HNNS samples with $\mathrm{N}$ contents of $>1.0 \mathrm{wt} . \%$. The matrix structure was not uniform, and a nitride layer was formed at the boundary. When the matrix was treated with solid-solution at $1200^{\circ} \mathrm{C}$, the structure showed a uniform austenite phase.

(2) After immersion in $6 \% \mathrm{FeCl}_{3}$ solution at $55^{\circ} \mathrm{C}$ for $72 \mathrm{~h}$, the corrosion weight loss rates of the samples with $\mathrm{N}$ contents of $1.19,1.28$, and 1.37 wt.\% decreased to $1.74 \times 10^{-5}, 1.43 \times 10^{-5}$, and $1.11 \times 10^{-5} \mathrm{~g} \mathrm{~mm}^{-2} \mathrm{~h}^{-1}$, respectively. The corresponding corrosion depths decreased to 178.29, 145.39 , and $118.01 \mu \mathrm{m}$, respectively. Therefore, the size and depth of the corrosion pits on the corroded surface decreased with increasing $\mathrm{N}$ content.

(3) With an increase in the N content of HNNS from 1.19 to $1.37 \mathrm{wt} . \%$, its corrosion current density decreased from $5.96 \times 10^{-7}$ to $3.14 \times 10^{-7} \mathrm{~A} \mathrm{~cm}^{-2}$, whereas its capacitive reactance arc radius increased. After the equivalent circuit was employed, the passivation film resistance of the HNNS samples with $\mathrm{N}$ contents of $1.19,1.28$, and 1.37 wt.\% increased to $1.51 \times 10^{5}, 2.38 \times 10^{5}$, and $2.91 \times 10^{5}$, respectively.

(4) The excellent corrosion resistance of HNNS can be attributed to the presence of a large amount of solidsolution $\mathrm{N}$ in the matrix.

\section{Data Availability}

The data used to support the findings of this study are available from the corresponding author upon request.

\section{Conflicts of Interest}

The authors declare that there are no conflicts of interest regarding the publication of this study.

\section{Acknowledgments}

The authors thank Dr. Ning Wu and Dr. Haojun Zhou from Central South University for the informative discussions on the powder metallurgy gas-solid nitriding method and solidsolution treatment process feasibility. Mr. Mingchu Huang and Dr. Chen Wang at Central South University are acknowledged for their assistance with the XRD and OM. The authors are grateful to Mr. Chrisna Mea and Mr. Manoj Aravind from Editage Co. Ltd., Shanghai, China, for scrupulously polishing the English language of the study. The authors are grateful for the financial support from major projects of Changsha Science and Technology Plan (Grant no. kh2003014) and Strategic Emerging Industry Technology Research and Major Technology Achievement Transformation Project of Hunan Province (Grant no. 2019GK4002).

\section{References}

[1] H. Li, E. Zhou, Y. Ren et al., "Investigation of microbiologically influenced corrosion of high nitrogen nickel-free stainless steel by Pseudomonas aeruginosa," Corrosion Science, vol. 111, pp. 811-821, 2016.

[2] C. Garcia-cabezon, Y. Blanco, M. L. Rodriguez-Mendez, and F. Martin-Pedrosa, "Characterization of porous nickel-free austenitic stainless steel prepared by mechanical alloying," Journal of Alloys and Compounds, vol. 716, pp. 46-55, 2017.

[3] Y. Lang and X. Kang, "Corrosion resistance of high nitrogen superaustenitic stainless steel and influence of nitrogen," Journal of Iron and Steel Research International, vol. 13, pp. 30-35, 2001.

[4] H.-Y. Ha, C.-H. Lee, T.-H. Lee, and S. Kim, "Effects of nitrogen and tensile direction on stress corrosion cracking susceptibility of ni-free FeCrMnC-based duplex stainless steels," Materials, vol. 10, no. 3, p. 294, 2017.

[5] M. Szala and D. Łukasik, "Pitting corrosion of the resistance welding joints of stainless steel ventilation grille operated in swimming pool environment," International Journal of Corrosion, vol. 2018, Article ID 9408670, 7 pages, 2018.

[6] P. Lochyński, S. Charazińska, M. Karczewski, and E. Łyczkowska-Widłak, "A multi-factorial mathematical model for the selection of electropolishing parameters with a view to reducing the environmental impact," Scientific Reports, vol. 11, no. 1, p. 9443, 2021.

[7] J. M. Bastidas, J. L. Polo, C. L. Torres, and E. Cano, "Study on the stability of AISI 316L stainless steel pitting corrosion through its transfer function," Corrosion Science, vol. 43, no. 2 , pp. 269-281, 2021.

[8] J. W. Simmons, D. G. Atteridge, and J. Rawers, "Microstructural characterization of as-cast high-nitrogen $\mathrm{Fe}-15 \mathrm{Cr}$ $15 \mathrm{Ni}$ alloys," Journal of Materials Science, vol. 27, no. 22, pp. 6105-6115, 1992. 
[9] J. W. Simmons, "Overview: high-nitrogen alloying of stainless steels," Materials Science and Engineering A, vol. 207, no. 2, pp. 159-169, 1996.

[10] J. Moon, H. Y. Ha, and T. H. Lee, "Corrosion behavior in high heat input welded heat-affected zone of Ni-free high-nitrogen Fe-18Cr-10Mn-N austenitic stainless steel," Materials Characterization, vol. 82, pp. 113-119, 2013.

[11] H. Li, Z. Jiang, M. Shen, and X. You, "High nitrogen austenitic stainless steels manufactured by nitrogen gas alloying and adding nitrided ferroalloys," Journal of Iron and Steel Research International, vol. 14, no. 3, pp. 64-69, 2007.

[12] H. Hänninen, J. Romu, R. Ilola, J. Tervo, and A. Laitinen, "Effects of processing and manufacturing of high nitrogencontaining stainless steels on their mechanical, corrosion and wear properties," Journal of Materials Processing Technology, vol. 117, no. 3, pp. 424-430, 2001.

[13] Z.-w. Xu, C.-c. Jia, C.-j. Kuang, and X.-h. Qu, "Fabrication and sintering behavior of high-nitrogen nickel-free stainless steels by metal injection molding," International Journal of Minerals, Metallurgy, and Materials, vol. 17, no. 4, pp. 423-428, 2010.

[14] V. G. Gavriljuk, B. D. Shanina, and H. Berns, "Ab initio development of a high-strength corrosion-resistant austenitic steel," Acta Materialia, vol. 56, no. 18, pp. 5071-5082, 2008.

[15] J. J. Romu, J. J. Tervo, H. E. Hänninen, and J. Liimatainen, "High nitrogen steels. development of properties of $\mathrm{P} / \mathrm{M}$ austenitic stainless steels by nitrogen infusion," ISIJ International, vol. 36, no. 7, pp. 938-946, 1996.

[16] Y. Katada, M. Sagara, Y. Kobayashi, and T. Kodama, "Fabrication of high strength high nitrogen stainless steel with excellent corrosion resistance and its mechanical properties," Materials and Manufacturing Processes, vol. 19, no. 1, pp. 19-30, 2004.

[17] S. Ahila, B. Reynders, and H. J. Grabke, "The evaluation of the repassivation tendency of $\mathrm{Cr}-\mathrm{Mn}$ and $\mathrm{Cr}-\mathrm{Ni}$ steels using scratch technique," Corrosion Science, vol. 38, no. 11, pp. 1991-2005, 1996.

[18] D. López, N. A. Falleiros, and A. P. Tschiptschin, "Corrosionerosion behaviour of austenitic and martensitic high nitrogen stainless steels," Wear, vol. 263, no. 1-6, pp. 347-354, 2007.

[19] Y. S. Yoon, H. Y. Ha, T. H. Lee, and S. Kim, "Comparative study of stress corrosion cracking susceptibility of Fe18Cr10Mn- and Fe18Cr10Mn1Ni-based high nitrogen stainless steels," Corrosion Science, vol. 88, pp. 337-348, 2014.

[20] H. Baba, T. Kodama, and Y. Katada, "Role of nitrogen on the corrosion behavior of austenitic stainless steels," Corrosion Science, vol. 44, no. 10, pp. 2393-2407, 2002.

[21] H. Li, Z. Jiang, Z. Zhang, Y. Cao, and Y. Yang, "Intergranular corrosion behavior of high nitrogen austenitic stainless steel," International Journal of Minerals Metallurgy and Materials, vol. 16, no. 6, pp. 654-660, 2009.

[22] W.-C. Jiao, H.-B. Li, J. Dai et al., "Effect of partial replacement of carbon by nitrogen on intergranular corrosion behavior of high nitrogen martensitic stainless steels," Journal of Materials Science \& Technology, vol. 35, no. 10, pp. 2357-2364, 2019.

[23] Y. Sun, P. A. Dearnley, and B. Mallia, "Response of duplex $\mathrm{Cr}(\mathrm{N}) / \mathrm{S}$ and $\mathrm{Cr}(\mathrm{C}) / \mathrm{S}$ coatings on $316 \mathrm{~L}$ stainless steel to tribocorrosion in $0.89 \% \mathrm{NaCl}$ solution under plastic contact conditions," Journal of Biomedical Materials Research Part B: Applied Biomaterials, vol. 105, no. 6, pp. 1503-1513, 2017.

[24] X. Xu, S. Liu, X. Han, and J. Bao, "Microstructure and antioxidation mechanism of an Fe-Cr-Al-Si heat resistant steel," Transactions of Materials and Heat Treatment, vol. 38, pp. 106-111, 2017.
[25] F. M. Bayoumi and W. A. Ghanem, "Effect of nitrogen on the corrosion behavior of austenitic stainless steel in chloride solutions," Materials Letters, vol. 59, no. 26, pp. 3311-3314, 2005.

[26] M. Szala, G. Winiarski, Ł. Wójcik, and T. Bulzak, "Effect of annealing time and temperature parameters on the microstructure, hardness, and strain-hardening coefficients of 42CrMo4 steel," Materials, vol. 13, no. 9, p. 2022, 2020.

[27] J. Toribio, B. González, J.-C. Matos, and F.-J. Ayaso, "Influence of microstructure on strength and ductility in fully pearlitic steels," Metals, vol. 6, no. 12, p. 318, 2016.

[28] P. Shankar, D. Sundararaman, and S. Ranganathan, "Clustering and ordering of nitrogen in nuclear grade 316LN austenitic stainless steel," Journal of Nuclear Materials, vol. 254, pp. 1-8, 1998.

[29] F. Shi, L. Wang, W. Cui, and C. Liu, "Precipitation kinetics of $\mathrm{Cr} 2 \mathrm{~N}$ in high nitrogen austenitic stainless steel," Journal of Iron and Steel Research International, vol. 15, no. 6, pp. 72-77, 2008.

[30] S. Zhang, Z. Jiang, H. Li et al., "Precipitation behavior and phase transformation mechanism of super austenitic stainless steel S32654 during isothermal aging," Materials Characterization, vol. 137, pp. 244-255, 2018.

[31] D. P. Guo, S. K. Xue, and C. Y. Wang, "Electrochemical evaluation for porosity of electroless plating Ni-P coating," Materials Protection, vol. 40, no. 9, pp. 28-30, 2007.

[32] Z. R. Zhang, Z. Y. Zhao, C. Z. Li, Z. H. Jiang, and H. B. Li, "Effects of aging precipitates on the mechanical and corrosion resistance properties of $18 \mathrm{Cr}-18 \mathrm{Mn}-2 \mathrm{Mo}-0.96 \mathrm{~N}$ super high nitrogen austenitic stainless steel," Applied Mechanics and Materials, vol. 395-396, pp. 284-288, 2013.

[33] X. Wu, Y. Fu, J. Huang et al., "Investigation on pitting corrosion of nickel-free and manganese-alloyed high-nitrogen stainless steels," Journal of Materials Engineering and Performance, vol. 18, no. 3, pp. 287-298, 2009.

[34] A. Di Schino and J. M. Kenny, "Effect of grain size on the corrosion resistance of a high nitrogen-low nickel austenitic stainless steel," Journal of Materials Science Letters, vol. 21, no. 24, pp. 1969-1971, 2002.

[35] H. Baba and Y. Katada, "Effect of nitrogen on crevice corrosion in austenitic stainless steel," Corrosion Science, vol. 48, pp. 2510-2524, 2006.

[36] F. Zanotto, V. Grassi, A. Balbo, C. Monticelli, and F. Zucchi, "Stress corrosion cracking of LDX 2101 duplex stainless steel in chloride solutions in the presence of thiosulphate," Corrosion Science, vol. 80, pp. 205-212, 2014.

[37] A. Igual Muñoz, J. García Antón, J. L. Guiñón, and V. Pérez Herranz, "Inhibition effect of chromate on the passivation and pitting corrosion of a duplex stainless steel in LiBr solutions using electrochemical techniques," Corrosion Science, vol. 49, pp. 3200-3225, 2007.

[38] R.-H. Jung, H. Tsuchiya, and S. Fujimoto, "XPS characterization of passive films formed on Type 304 stainless steel in humid atmosphere," Corrosion Science, vol. 58, pp. 62-68, 2012.

[39] L. Reclaru, R. Ziegenhagen, P.-Y. Eschler, A. Blatter, and J. Lemaître, "Comparative corrosion study of "Ni-free" austenitic stainless steels in view of medical applications," Acta Biomaterialia, vol. 2, no. 4, pp. 433-444, 2006.

[40] H. J. Grabke, "High nitrogen steels. the role of nitrogen in the corrosion of iron and steels," ISIJ International, vol. 36, no. 7, pp. 777-786, 1996.

[41] E. A. Merkushkin, V. V. Berezovskaya, and M. Shpaidel, "Prediction of corrosive characteristics of high-nitrogen austenite steels based on correlation equation of pitting 
potential," Inorganic Materials: Applied Research, vol. 8, no. 4, pp. 491-493, 2017.

[42] P. L. An, P. Liang, Y. X. Zhang, F. Liu, Y. H. Shi, and Y. Zhao, "Study on pitting corrosion of high nitrogen austenitic stainless steels," Materials Protection, vol. 50, no. 7, pp. 34-36, 2017. 